\title{
ロボットハンド遠隔操作における触覚・カ覚フィードバック
}

\section{Haptic Feedback in Universal Robot Hand Tele-Operation}

\author{
神戸大学 ○齋藤 裕, 小林 太, 小島史男, \\ 兵庫工業技術センター 中本裕之, (株) 前田精密製作所 前田正, 広島国際大 今村信昭, \\ 関西電力 (株) 笹部和宏, AMPI 白沢秀則
}

Yu SAITO, Futoshi KOBAYASHI, and Fumio KOJIMA, Kobe University. Hiroyuki NAKAMOTO, Hyogo Pref. Inst. Of Tech.

Tadashi MAEDA, MAEDA PRECISION MANIFUCTURING.

Nobuaki IMAMURA, Hiroshima International univ

Kazuhiro SASABE, KEPCO.

Hidenori SHIRASAWA, AMPI

\begin{abstract}
Human hand is a multifunctional end effctor which is widely used for various purposes. The purpose of our study is to realize dexterous manipulation task with tele-operating universal robot hand which has the same capability as human hand. To realize dexterous manipirlation task with robot hand, force and tactile infomation are indispensable. So we develop a robot hand tele-operation system which displays force infomation of universal robot hand using haptic interface, and shows tactile infomation on the computer screen. In this paper, we verify effects of force and tactile feedback in robot hand tele-operation through the universal robot hand tele-operation experiment.
\end{abstract}

Keywords: Robot Hand, Tele-operation, Feedback

\section{1 緒言}

近年のロボット技術の発達は目覚しいものがあり、ロボット は製造現場や実験室などの限られた環境だけでなく，医療現場 やオフィスなど人間の生活に密接に関わる環境においても用い られるようになってきた。、ボットに，人の手のように多様な機 能を有するロボットハンドシステムが装備されれば,これまで 人間に頼らざるを得なかった危険環境下での複雑な作業, 製造 現場での不定形物のピッキング作業などに適用が期待され，产 業界で極めて有用である [1]. しかし，危険環境下での作業の場 合, すべての作業をロボットハンドが白律的に行うことは非常 に困難であるため、ロボットハンドを的確に操作できる遠隔操 作システムが必要とされている.

本講演では， ロボットハンドの遗隔操作において，操作者に 触覚・力覚フィードバックを提示することで, 操作性の向上を 目指す。我々の研究グループは, 人の手とほぼ同等の構造を持 ち, 触覚センサと力覚センサを備えたユニバーサルロボットハ ンドシステムを開発してきた [2]. また、現在までに, このユニ バーサルロボットハンドの遠隔操作操作システムとして、人の 手の動きを計測し，それに基づきユニバーサルロボットハンド を制御するシステムを構築した。また，本システムでは，操作 者が遠隔地での作業の感覚を認識するために，ユニバーサルロ ボットハンドで計测した触覚及び力覚を操作者に提示する。触 覚情報はそのまま操作者の触覚に提示することが困難であるた め, 別のモダリティである視覚情報に変換して提示する [3]. 本 システムでロボットハンドの遠隔操作実験を行い,フィードバッ クにより操作性が向上していることを示す。

\section{2 ユニバーサルロボットハンドの概要}

Fig. 1 に開発したユニバーサルロボットハンドシステムを示 す. 本システムは, 触覚情報処理系と運動感覚処理系, 遠隔操作 系の3つの処理系からなる. 各処理を分散させることによりシ ステム全体の処理速度が向上し,より高速なハンドの制御が可能 になっている.

ハンドはアルミを忉質とした 5 本の指と手のひらから構成さ れ，各指の長さはそれぞれ約 $340[\mathrm{~mm}]$ となっている。指は队部 にモータを組み込んだアクチュエータ内蔵型になっている.小 型のモータでありながら最大トルク $1.1[\mathrm{Nm}]$ とその底部にエン コーダ機能を有する. 各指は 4 関節を有するが第 1 関節と第 2 関 節はシャフトとギアによって $1: 1 て ゙$ 連動している $\left(\theta_{1}=\theta_{2}\right)$.こ れは人間の手指の機構を模倣したものである.指 1 本あたりの白 由度を少なくすることによってハンドの操作を容易にする.

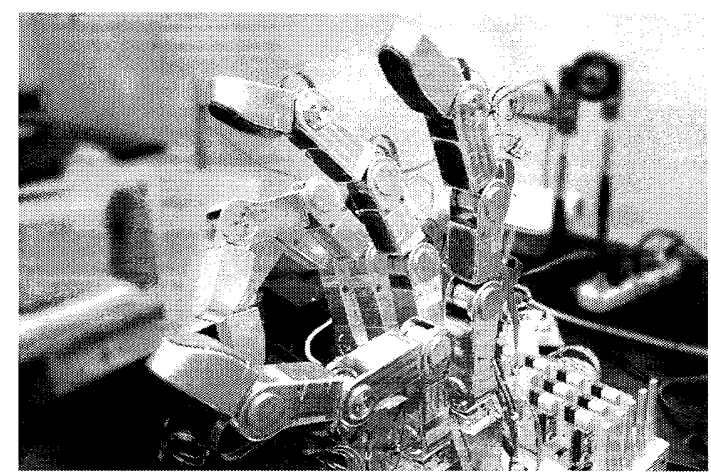

Fig. 1: Universal Robot Hand System

物休と接強する表面部には, 人間の皮膚を再現するために柔 軟で浡りの少ないウレタンゲルを用いた。この触覚センサでは, 2 層目の感压導電性:ゴムの変形によって発生する電圧を 3 層目の 電極で感知し出力する. 感圧導電性 ゴムを用いた触覚センサでは 圧力の分布を計測することが可能である.

\section{3 ロボットハンド遠隔操作システム}

Fig. 2 に提案するロボットハンド遠隔操作システムを示す。本 システムにおいて、操作者の手の動きをロボットに模倣させること から, 人の手の動きを計測するため, Immersion 社の CyberGlove を使用する。 また，ユニバーサルロボットハンドに搭載された トルクセンサを用いて計測する力覚情報 (操作感覚) を反力で力 覚的に操作者に提示するため, SensAble 社の PHANTOM Omni を使用する。ささらに, 遠隔操作系において, 触覚センサで計測 する触覚情報を視覚的に提示する。

3.1 指先位置に基づく遠隔操作 人の手の動きを基に, ユニ バーサルロボットハンドを制御する方法として, CyberGlove で 計测した人の手の関節估度をコニバーサルロボットハンド各関 節の目標的度として，関節的度制御を行う方法が一般的である。 しかし，ユニバーサルロボットハンドの拇指の構造は，人の拇 指の構造と異なっており, 上記方法で制御した場合, 拇指とそ の他指が丁渉してしまうという問題が生じる．そこで，本講演 では人の指先位置に基づき、ユニバーサルロボットハンドを指 先位置に基づき制御する方法をとる。ここで，人の手をモデル 化し，CyberGlove で計測した関節色度から，人の指先位置を求 


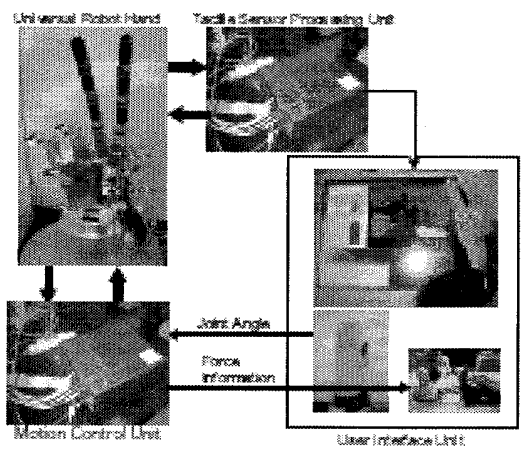

Fig. 2: Robot Hand Tele-Operation System

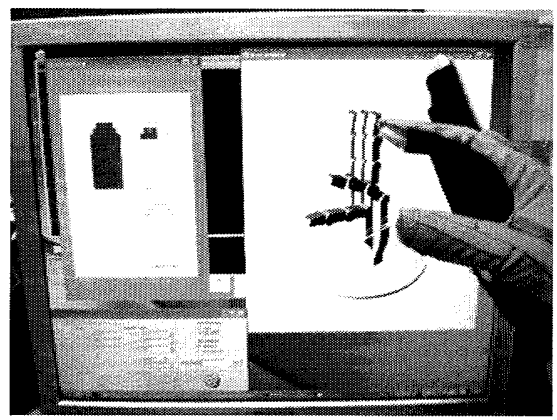

Fig. 3: Contact Display based on Tactile Infomation

める. ユニバーサルロボットハンドの制御では，人の指先位置. から日標指先位置を定め, 逆運動学を解くことで各関節目標的 度を求め, 制御を行った。

3.2 力覚フィードバック PHANTOM Omni を用いた力覚フ ィードバックでは, トルクセンサで計測する力覚情報を, 別に 求めた同時变換行列を用いて PHANTOM Omni の座標系に変換 する. この変換される力覚情報を PHANTOM Omni に与えるこ とにより，操作者の指にその反力の形で力覚情報を提示する.

3.3 触覚フィードバック 触覚フィードバックでは, 触覚情 報を別のモダリティである視覚情報に变換して提示を行う。口 ボットハンドに装備されている触覚センサで取得した指表面の 压力分布情報を, 触覚センサの形を模したグラフィックモデル によりディスプレイ上に提示する. Fig. 3 に示されているよう にグラフィックモデルの色の変化により，操作者はロボットハン ドの指が物体に触れた際の接触位置, その位置での圧力を視認 することができる。

\section{4 評価実験}

力覚・触覚情報をフィードバックすることの有効性をを示すた め, ユニバーサルロボットハンドを遠隔操作してタッピング動 作を行い、提示しなかった場合との比較を行なった。

被騟者数名に, 以下の条件でそれぞれ 100 回タッピング動作 を行なってもらった。

1. 力覚情報、螌覚情報共に提示しない

2. 力覚情報のみ提示する

3. 触覚情報のみ提示する

4. 力覚情報、触覚情報共に提示する

それぞれの条件において，ロボットハンドが物体に触れた際 の, 力覚トルクのピーク值の平均值, 力覚トルクのピーク值の 不偏分散, 接触してから被験者が感知するまでの平均時間を計 測し，力覚情報，触覚情報共に提示しない場合のデー夕を基準 値 1 として比較を行なった。

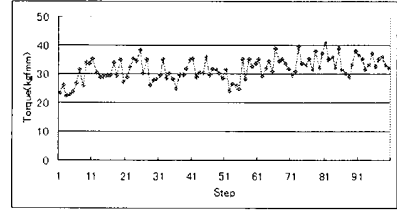

Fig. 4: Without Feedback

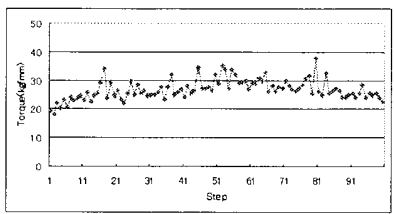

Fig. 6: Tactile Feedback

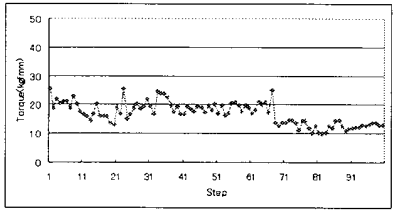

Fig. 5: Force Feedback

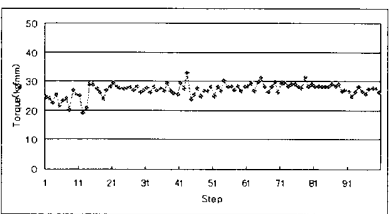

Fig. 7: Force and Tactile
Experiment Data

\begin{tabular}{|c|c|c|c|}
\hline Data \Feedback & Force & Tactile & Force+Tactile \\
\hline Peak Torque & 0.69026 & 0.64661 & 0.75288 \\
\hline Torque Variance & 0.77050 & 1.15406 & 0.63375 \\
\hline Perception Time & 0.92813 & 0.61354 & 0.66440 \\
\hline
\end{tabular}

Table. 1 に被験者全員の比較值の平均を示す。この結果から， 触覚情報，力覚情報をフィードバックすることで，フィードバッ クがない場合に比べて，より少ない接触力で接触を感知できる ことがわかる。また，力覚フィードバックと触覚フィードバッ クを合わせることにより，力覚ピーク值の不偏分散が小さくな り, 灾定した接触力でタッピング動作を行っていることがわか る. さらに, 触覚フィードバックにより, 接触を感知するまで の時間が大幅に短縮されていることがわかる．これらのことか ら, 提案したシステムを用いることで, 接触認識までの時間や， 接触時の力が灾定していることから操作感が向上することを示 した. Fig. 4,5,6,7 に被験者のうちの一人の力覚ピーク值のデー 夕を示す

\section{5 結言}

本講演では，ロボットハンドを嗃隔操作する際の接触情報を 操作者に提示するシステムを構築した，我々が開発してきたユニ バーサルロボットハンドを用い，装備されたトルクセンサから の力覚情報を PHANTOM Omni を用いて提示した。 また，ユニ バーサルロボットハンドの操作は，人の手の動きをCyberGlobe により計测し，人の指先位置に基つく制御を行った。また， ユ ニバーサルハンドに搭載した触覚センサにより計測した触覚情 報を直接提示せず，他のモダリティである視覚情報として提示

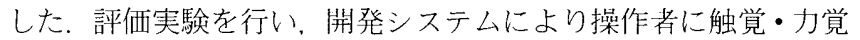
フィードバックを行うことで，操作感が向上することを示した．

\section{参考文献}

1) 小俣透: 器用な手, 日本ロボット学会誌 Vol.18 No.6, pp760$762(2000)$

2）上円健二郎，新納啓輔，小林太ほか：コニバーサルロボッ トハンドの開発と関節制御の㴊性評価, ROBOMEC'06 予稿 集, 1A1-B23(2006)

3）齋藤裕，小林太ほほか：ロボットハンド遠隔操作における 接触情報提示システム，SI2007 予稿集，2G3-6(2007) 